\title{
Improving the nutritional content of apple pomace using biological treatments as a nonconventional broiler feed
}

\author{
Irfan H Djunaidi*1), Yuli Frita Nuningtyas ${ }^{1)}$ and Muharlien ${ }^{2)}$ \\ ${ }^{1)}$ Department of Animal Nutrition and Feed, Faculty of Animal Science, Brawijaya \\ University, Jl. Veteran, Ketawanggede, Kec. Lowokwaru, Kota Malang, Jawa Timur \\ Indonesia 65145 \\ ${ }^{2)}$ Department of animal Production, Faculty of Animal Science, Brawijaya University, Jl. \\ Veteran, Ketawanggede, Kec. Lowokwaru, Kota Malang, Jawa Timur Indonesia 65145
}

Submitted: 28 September 2019, Accepted: 30 July 2020

\begin{abstract}
This study was aimed to evaluate apple pomaces using fermentation and enzymatic technology (Aspergillus niger and glucanase enzymes). Treatments in this research were used enzymatic technology (T1) and fermentation technology (T2) and the second factor of the level of enzyme used Aspergillus niger processing: without Aspergillus niger (L0), $0.2 \%$ Aspergillus niger (L1), 0.4\% Aspergillus niger (L2) and 0.6\% Aspergillus niger (L3) and treatment used Glucanase enzyme: without Glucanase (L0), 0.2\% Glucanase (L1), 0.4\% Glucanase (L2) and 0, 6\% Glucanase (L3). Data analysis used nested using a Completely Randomized Design. Based on the results of the study shows that fermentation technology using $0.6 \%$ glucanase gives better feed quality compared to the treatment using Aspergillus niger.
\end{abstract}

Keywords: Apple waste extraction; Aspergillus niger; Fermentation; Glucanase

*Corresponding Author: irjuna@gmail.com 


\section{INTRODUCTION}

The feed is the main aspect that determines the success of the livestock business. Meat production and quality are determined primarily by the quality of the feed provided, and the most dominant production cost is the cost of feed. Hence, the aspect of feeding is very important in determining production, meat quality, and cost-efficiency of broiler meat production. East Java is a center for poultry production, especially laying hens (Blitar and Malang) and broilers (Lamongan and Kediri) require the availability of feed, especially corn as an energy source feed.

Research in the context of finding alternative substitutes for corn has been carried out using conventional feed ingredients due to energy content quite similar and high availability in the Malang area. Apple production in the Greater Malang area (Batu and Malang Regency) is no less than 600 thousand quintals. Apples can be processed into chips and extraction of apple juice in addition to direct consumption. Approximately $50 \%$ of the fruit production is processed through apple extraction and produces waste extraction of apple pomace (AP) around 100,000 quintals per year.

The potential of this apple extraction waste (apple pomace) can be used as feed ingredients with high sugar and energy content $(2300 \mathrm{kcal} / \mathrm{kg} \mathrm{BK})$. The obstacle of using AP is fiber content, especially glucan and pectin, which are high, and poultry could not have the capacity to digest it. The use of AEA in broilers can only replace corn by $5 \%$. The application of enzymes is a rational alternative to increasing the amount of AEA use as an alternative feed source for corn. The fermentation treatment and enzymatic procedures were done in terms of improving protein and digestibility value, using Aspergillus niger and commercial glucanase product with the recommended doses level.

\section{MATERIALS AND METHODS Research Material Apple pomace}

Is used in the form of dry flour obtained from the apple juice producing company in the Batu city and dried in an oven by drying a low-temperature oven (60 ${ }^{\circ} \mathrm{C}$ ), and then ground by a $1 \mathrm{~mm}$ sieve grinder to obtain the uniform size. Furthermore, this material is fermented using Aspergillus niger and glucanase enzymes with different levels.

\section{Aspergillus niger}

Aspergillus niger was obtained from the Microbiology Laboratory, Mathematics and Natural Sciences, Brawijaya University. Glucanase Enzyme

Glucanase enzyme was obtained from the Microbiology Laboratory, Mathematics and Natural Sciences, Universitas Brawijaya.

\section{Research methods Fermentation}

The media used for fermentation is apple extract pulp. Apple extract pulp is obtained from an apple cider beverage processing plant in Batu Malang. The pulp of the apple extract is sun-dried or dried until the water content drops to as low as $20 \%$ (brownish). They were then dried using an oven temperature of $60^{\circ} \mathrm{C}$ to $15 \%$ water content. After $15 \%$ moisture content, the pulp is ground using a $1 \mathrm{~mm}$ mesh grinder. The apple extract pulp is steamed for 30 minutes and cooled to a temperature of 35 ${ }^{\circ} \mathrm{C}$. Every $200 \mathrm{~g}$ of steamed apple extract pulp is mixed with Aspergillus niger and glucanase enzymes, and incubated for 48 hours. Afterward, the treated AP was dried on the oven at $80^{\circ} \mathrm{C}$ to stop the fermentation process and enzyme activity, then ground. The Enzymated apple pomace (EAP) was ready as feedstuff.

The treatment used is the first factor, namely the type of enzymatic processing (Glucanase) (T1) and fermentation technology (Aspergillus niger) (T2), 
wherein each treatment five repetitions are performed. The treatments in each treatment are P0 (control), P1 (0.02\%), P2 (0.04\%), P3 $(0.06 \%)$ and $\mathrm{P} 4(0.08 \%)$. The variables observed were dry matter (DM), organic matter, crude protein $(\mathrm{CP})$. Crude fibre $(\mathrm{CF})$ and extract eter (EE) nutrition contents.

\section{Statistic analysis}

Data obtained from the study were analyzed by statistical calculations. The thematic model for all observations using the experimental design used in this study is a complete random design (CRD) pattern of a nested/nested design (Steel and Torrie, 1993).

\section{RESULTS AND DISCUSSION}

Based on the research results of apple pulp waste fermentation using Aspergillus niger and glucanase treatment with treatment levels of $0,0.2,0.4,0.6$, and $0.8 \%$ can be seen in Table 1 below.

Table 1. Nutritional Content of apple Extracts (AEA) fermented using Aspergillus niger and Glucanase

\begin{tabular}{ccccccc}
\hline \multirow{2}{*}{ Treatments } & Level $(\%)$ & \multicolumn{5}{c}{ Nutrient Contents } \\
\cline { 3 - 6 } & 0 & Dry matter & Org matter* & Crude protein* & Crude fiber* & Crude fat* $^{*}$ \\
\hline \multirow{2}{*}{$\begin{array}{c}\text { Aspergillus } \\
\text { niger }\end{array}$} & 0,2 & $90,85 \pm 0,24^{\mathrm{a}}$ & $96,99 \pm 0,12$ & $1,95 \pm 0,08$ & $9,08 \pm 0,12$ & $1,21 \pm 0,06^{\mathrm{b}}$ \\
& 0,4 & $93,64 \pm 0,16^{\mathrm{d}}$ & $95,12 \pm 0,05$ & $2,83 \pm 0,09$ & $8,28 \pm 0,31$ & $0,92 \pm 0,10^{\mathrm{ab}}$ \\
& 0,6 & $91,55 \pm 0,34^{\mathrm{c}}$ & $95,22 \pm 0,06$ & $3,11 \pm 0,16$ & $8,15 \pm 0,61$ & $0,87 \pm 0,09^{\mathrm{ab}}$ \\
& 0,8 & $94,30 \pm 0,20^{\mathrm{d}}$ & $95,47 \pm 0,08$ & $4,22 \pm 0,94$ & $8,48 \pm 0,63$ & $0,72 \pm 0,16^{\mathrm{a}}$ \\
\hline \multirow{2}{*}{ Glucanase } & 0 & $68,85 \pm 0,24^{\mathrm{a}}$ & $96,99 \pm 0,26^{\mathrm{c}}$ & $1,95 \pm 0,08^{\mathrm{a}}$ & $9,08 \pm 0,13^{\mathrm{d}}$ & $1,21 \pm 0,06^{\mathrm{bc}}$ \\
& 0,2 & $92,14 \pm 0,86^{\mathrm{b}}$ & $94,26 \pm 0,38^{\mathrm{b}}$ & $5,38 \pm 2,62^{\mathrm{b}}$ & $8,27 \pm 0,56^{\mathrm{cd}}$ & $0,85 \pm 0,22^{\mathrm{ab}}$ \\
& 0,4 & $92,44 \pm 0,41^{\mathrm{b}}$ & $91,88 \pm 2,13^{\mathrm{a}}$ & $3,75 \pm 0,57^{\mathrm{ab}}$ & $7,69 \pm 0,32^{\mathrm{bc}}$ & $0,71 \pm 0,24^{\mathrm{a}}$ \\
& 0,6 & $91,92 \pm 0,08^{\mathrm{b}}$ & $92,18 \pm 0,44^{\mathrm{a}}$ & $5,35 \pm 1,05^{\mathrm{b}}$ & $6,72 \pm 0,27^{\mathrm{ab}}$ & $0,70 \pm 0,15^{\mathrm{a}}$ \\
& 0,8 & $91,87 \pm 0,73^{\mathrm{b}}$ & $90,94 \pm 0,53^{\mathrm{a}}$ & $5,83 \pm 1,45^{\mathrm{b}}$ & $6,00 \pm 0,39^{\mathrm{a}}$ & $1,39 \pm 0,10^{\mathrm{c}}$ \\
\hline
\end{tabular}

*Different superscript in the same column show very significant differences $(\mathrm{P}<0.01)$

Effect of the level of $A$. niger and glucanase enzymes on apple pomace on the dry matter content

Based on the treatment of Aspergillus niger and glucanase enzymes in apple pomace showed any significant difference effect $(\mathrm{P}<0.01)$ on the dry matter. The dry matter content in the treatment of $A$ niger was $87.77 \%$ and in the enzyme glucanase $87.47 \%$. The content of dry matter in the treatment of Aspergillus niger is higher than in the treatment of the glucanase enzyme. The significant difference between the treatment of $A$ niger and the glucanase enzyme is caused by the drying process using the same temperature. The increased DM in Aspergillus treatment is caused by the water content in the feed used by
Aspergillus as a microbe for growth. Dry matter is strongly influenced by water content. In the fermentation process, the water needed by Aspergillus is very high.

Increased dry matter in fermented feed due to the need for water content by Aspergillus as energy to break down complex compounds into simple compounds. During the fermentation process, the $A$. niger needs more water compared to Glucanase, the microbes proceed longer and need water since their initial growth until the exponential phase and produced enzymes. With a higher level, A. niger was added, need more water to produces the enzyme, and treat the feedstuff. The level of glucanase enzyme also has a significant effect on DM. A higher 
glucanase enzyme added needs more water to initial fermentation processes, due to water is a vital nutrient component of the enzyme process. The enzyme will be active and treated the feedstuff when the water content available enough (Papagianni and Mattey, 2005).

Effect of the level of $A$. niger and glucanase enzymes on apple pomace on the organic matter content

Based on the treatment of $A$ niger and glucanase enzymes in apple pomace showed a significant difference $(\mathrm{P}<0.05)$ of organic matter. The content of organic matter in the treatment of $A$ niger was $95.55 \%$ and in the glucanase enzyme $93.25 \%$. High or low content of organic matter in the treatment is also likely caused by the presence of microbial activity in the fermentation process that causes the breakdown of the substrate content making it easier for microorganisms to digest organic matter, increasing the mass of cell growth in molds and an increase in concentration in the product due to a decrease organic material due to the fermentation process that produces $\mathrm{CO} 2$ and reflects heat. According to Darwin et al. (2018) that Loss of organic material that occurs during the fermentation process is due to the decomposition of organic matter, especially carbohydrates, to be used as an energy source for growth and activity of molds. The carbohydrate will be broken down into glucose and then continued until energy is formed. From this process, the byproducts such as $\mathrm{CO} 2$ and $\mathrm{H} 2 \mathrm{O}$ will be obtained.

Increased metabolic energy (ME) value after fermentation is done. This is most likely due to a decrease in crude fiber content, and this causes an increase in the ash content of the material along with the increasing population of Aspergillus niger on fermented cassava peel flour. Increased mold cell growth and increased concentration in the product due to changes in organic materials due to bioconversion processes that produce $\mathrm{H} 2 \mathrm{O}$ and $\mathrm{CO} 2$ (Sadiq et al., 2019). Giving Aspergillus niger level in apple pomace can improve the quality of feed ingredients. This is due to the increase in mold cell mass and the increase in concentration in the product. According to Smith et al. (2018) states that fermentation can increase the availability of minerals for livestock. The change of organic materials degraded by microorganisms into organic compounds from substrates into simpler molecules and other forms such as water and energy used for microorganism activities.

Effect of the level of $A$. niger and glucanase enzymes on apple pomace on crude protein

Based on the treatment of Aspergillus niger and glucanase enzymes in apple, pomace showed a significant difference $(\mathrm{P}$ $<0.05)$ to crude protein. The crude protein content in Aspergillus niger treatment was $3.39 \%$, and in an enzyme, Glucanase was $4.45 \%$. This is by the opinion of Zakariah (2012), which states that fermentation is the process of breaking down organic compounds into simple ones involving microorganisms. The fermentation process can increase the availability of food substances such as protein and metabolic energy and can break down complex components into simple components

To obtain optimum fermentation results, the requirements for yeast growth must be considered $\mathrm{pH}$ and carbohydrate content of the substrate, temperature during fermentation, purity of the yeast itself. The addition of Aspergillus niger levels in each treatment was still able to increase the protein content. Increased protein content after fermentation is thought to originate from the fungus Aspergillus niger, which has synthesized the urease enzyme to break down urea to ammonia and $\mathrm{CO} 2$, which is then used by the fungus to form amino acids/protein (Sadiq et al., 2019). Increased pure protein content caused by urea being able to stimulate the growth of the fungus Aspergillus niger, increasing the number of mold cells.

The protein of the treated AP increase due to contribution crude protein content contributed from microbes and enzyme its self. The A niger and Glucanase composed 
of protein and will be growth and produce protein as a microbes biomass increased. During the fermentation process, the NPN of the AP will be converted to protein by A niger or glucanase works and will produce more amino acids and protein, particularly during the exponential phase of the fermentation process.

Effect of the level of $A$. niger and glucanase enzymes on apple pomace on crude fiber

Based on the treatment of Aspergillus niger and glucanase enzymes in apple, pomace showed a significant difference $(P$ $<0.05$ ) of crude fiber. The content of crude fiber in the treatment of Aspergillus niger is $8.50 \%$, and in the glucanase enzyme is $7.40 \%$. Decreased levels of crude fiber along with the increasing ripening time accompanied by variations in the A. niger level because this mold can break lignocellulose aerobically is superior to other microbes.

This is following the opinion of Ihtifazhuddin et al (2016) which states that the decrease in fiber content in the treatment is caused by the enzymes produced by A. niger being able to break down cellulose during the process of fermentation into glucose, which cellulose enzyme is a complex enzyme that works in stages to break down cellulose into glucose. Glucose produced from the substrate will be used as a source of carbon and energy because glucose is the most important carbon source of their daily needs. Decreased crude fiber content is consistent with a decrease in NDF levels because A. niger utilizes cell contents (NDS) to support its growth.

NDS consists of protein, carbohydrates, and soluble minerals and fats. The glucanase enzyme works degraded crude fiber compared to A niger. The enzyme used in this experiment is a cocktail enzyme, contain not only Glucanase but also other type enzyme included cellulase and other fiber degrading enzyme. In the higher glucanase level treatment, the fiber content lower. This indicated that the Glucanase works effectively when the amount of enzyme level added based on the amount of apple pomace use as fermentation media.

Effect of the level of $A$. niger and glucanase enzymes on apple pomace on crude fat

Based on the treatment of $A$ niger and glucanase enzymes in apple pomace showed no significant difference $(\mathrm{P}>0.05)$ to crude fat. The crude fat content in the treatment of A niger is $0.93 \%$, and the glucanase enzyme is $0.97 \%$. This is consistent with the opinion of Ronzio (2003) that mold after attacking carbohydrates for energy sources, then attack fats and proteins. The more use of feed ingredients containing glucose in the substrate can stimulate the growth of mold biomass resulting in the production of more lipase enzymes.

Factors that influence the difference in the reduction of crude fat are the original crude fat content of the substrate that stimulates the activity of the lipase enzyme and the production of the lipase enzyme, which is influenced by the growth of mold biomass. There is a significant effect of the treatment type on the crude fat content. The A niger fermentation showed a lower CF compared to glucanase treatment.

The level of $A$ niger or glucanase level tends to lower the crude fat of the fermentation media. Glucanase enzyme changed the absorption rate of fat, cholesterol, and bile acids. Both, the fermentation process utilized fat as a nutrient for microbe growth or enzyme process. More levels of treatment also look to decrease the crude fat content of the apple pomace as fermentation media.

\section{CONCLUSION}

Both Aspergillus niger and glucanase enzymes can improve the nutritional quality of apple pomace, particularly on increasing crude protein and crude fat content and lowering crude fiber content. Treatment with $0,6 \%$ glucanase enzyme and $0,8 \% \mathrm{~A}$. niger produced the highest nutrient content of apple pomace. However, Glucanase enzyme treatment has a better effect on the nutrition content of the apple pomaces. 


\section{REFERENCES}

Darwin, Cord-Ruwisch, R., \& Charles, W. (2018). Ethanol and lactic acid production from sugar and starch wastes by anaerobic acidification. Engineering in Life Sciences, 18(9), 635-642. https://doi.org/10.1002/elsc. 201700178

Ihtifazhuddin, M. I., Nursyam, H., \& Ekawati, A. W. (2016). The Influence of Fermentation Time in the Physical and Chemical Composition of Fermented Soybean Husk by Using Aspergillus niger on the Quality of Raw Feed Materials. The Journal of Experimental Life Sciences, 6(1), 52 57. https://doi.org/10.21776/ub.jels.20 16.006.01.12

Nkhata, S. G., Ayua, E., Kamau, E. H., \& Shingiro, J.-B. (2018). Fermentation and germination improve nutritional value of cereals and legumes through activation of endogenous enzymes. Food Science \& Nutrition, 6(8), 24462458. https://doi.org/10.1002/fsn3.846
Papagianni, M., \& Mattey, M. (2006). Morphological development of Aspergillus niger in submerged citric acid fermentation as a function of the spore inoculum level. Application of neural network and cluster analysis for characterization of mycelial morphology. Microbial Cell Factories, 5(3), 1-12. https://doi.org/10.1186/14 75-2859-5-3

Ronzio, R. (2003). Nutrition and Good Health. United States of America.

Sadiq, F. A., Yan, B., Tian, F., Zhao, J., Zhang, H., \& Chen, W. (2019). Lactic Acid Bacteria as Antifungal and AntiMycotoxigenic Agents:

A Comprehensive Review. Comprehensive Reviews in Food Science and Food Safety, 18(5), 1403-1436. https://doi. org/10.1111/1541-4337.12481

Zakariah, M. (2012). Fermentasi Asam Laktat Pada Silase. Universits Gajah Mada. 